\title{
Circulating Cardiac Biomarkers in Diabetes Mellitus: A New Dawn for Risk Stratification-A Narrative Review
}

\author{
Alexander E. Berezin (D) - Alexander A. Berezin
}

Received: April 7, 2020 / Published online: May 19, 2020

(C) The Author(s) 2020

\begin{abstract}
The aim of this narrative review is to update the current knowledge on the differential choice of circulating cardiac biomarkers in patients with prediabetes and established type 2 diabetes mellitus (T2DM). There are numerous circulating biomarkers with unconfirmed abilities to predict clinical outcomes in pre-DM and DM individuals; the prognostication ability of the cardiac biomarkers reported here has been established, and they are still being studied. The conventional cardiac biomarkers, such as natriuretic peptides (NPs), soluble suppressor tumorigenisity-2, high-sensitivity circulating cardiac troponins and galectin-3, were useful to ascertain cardiovascular (CV) risk. Each cardiac biomarker has its strengths and weaknesses that affect the price of usage, specificity, sensitivity,
\end{abstract}

Digital Features To view digital features for this article go to: https://doi.org/10.6084/m9.figshare.12240407.

\section{A. E. Berezin $(\varangle)$}

Internal Medicine Department, Ministry of Health of Ukraine, State Medical University, Zaporozhye 69035, Ukraine

e-mail: aeberezin@gmail.com

\section{A. A. Berezin}

Internal Medicine Department, Medical Academy of Post-Graduate Education, Ministry of Health of

Ukraine, Zaporozhye 69096, Ukraine predictive value and superiority in face-to-face comparisons. Additionally, there have been confusing reports regarding their abilities to be predictably relevant among patients without known CV disease. The large spectrum of promising cardiac biomarkers (growth/differential factor-15, heart-type fatty acid-binding protein, cardiotrophin-1, carboxy-terminal telopeptide of collagen type 1 , apelin and noncoding RNAs) is discussed in the context of predicting $\mathrm{CV}$ diseases and events in patients with known prediabetes and T2DM. Various reasons have been critically discussed related to the variable findings regarding biomarker-based prediction of $\mathrm{CV}$ risk among patients with metabolic disease. It was found that NPs and hscTnT are still the most important tools that have an affordable price as well as high sensitivity and specificity to predict clinical outcomes among patients with pre-DM and DM in routine clinical practice, but other circulating biomarkers need to be carefully investigated in large trials in the future.

Keywords: Cardiac biomarkers; Cardiovascular risk; Prediabetes; Prognostication; Risk factors; Type 2 diabetes mellitus 


\section{Key Summary Points}

The role of diabetes mellitus as a cause of asymptomatic and symptomatic cardiac disease is progressively increasing.

Conventional biomarkers of cardiac biomechanical stress and myocardial injury have demonstrated limited predictive value for patients with prediabetes and diabetes mellitus.

Circulating biomarkers of fibrosis (soluble ST2) and inflammation (growthdifferentiation factor-15, galectin-3, cardiotrophin-1) are promising predictors of cardiac injury at an early stage.

Multiple biomarker predictive scores could be useful in personalizing stratification and care.

\section{INTRODUCTION}

Diabetes mellitus (DM) is a common metabolic disorder worldwide and has reached epidemic levels [1]. Type 2 DM (T2DM) comprises about $90 \%$ of the cases of the disease and affects $8.3 \%$ of the entire adult population [2]. It has been suggested that by 2035 about 592 million people will die of DM, and it will be one of the leading causes of mortality in the general population [3]. Although there are several wellestablished methods for the prevention and treatment of DM, the disease has been considered a powerful risk factor for cardiovascular (CV) disease, but evidence for a close relationship between various types of prediabetes, such as metabolically healthy obesity and metabolic syndrome, is still conflicting [4-6]. However, T2DM is closely linked to a substantial increase in all-cause mortality and CV mortality in the general population [7]. Therefore, DM patients with known CV diseases, including atherosclerosis, stable coronary artery disease (CAD), acute coronary syndrome/myocardial infarction
(MI), heart failure (HF), arrhythmia (atrial fibrillation and flutter) and cardiomyopathies, have a higher risk of death than non-diabetics with CV diseases [8-12].

In 2019, the European Society of Cardiology (ESC) announced a new clinical guideline on diabetes, pre-diabetes and CV diseases [13]. This recommendation contains a section on circulating cardiac biomarkers, which are promising prognostic indicators for $\mathrm{CAD}, \mathrm{HF}$ and major adverse CV events (MACEs) in DM patients. Notably, T2DM and diabetes-induced target organ damage have been considered factors that hinder clinical interpretations of circulating biomarkers' peak levels [14]. For instance, abdominal obesity in diabetics was associated with increased endogenous activity of neprilysin and thereby decreased the expected levels of circulating natriuretic peptides (NPs), which were previously proposed as powerful diagnostic and accurate prognostic biomarkers in HF [15]. Nowadays, there is an appropriate correction for the NP discriminative value in DM to calculate CV risk [16]. On the other hand, at the early stage of DM in elderly people without CV disease, the circulating levels of soluble suppressor tumorogenicity-2 were significantly increased compared with healthy elderly volunteers [17]. These data need to be evaluated carefully to prevent both over- and underestimation of CV disease risk and inadequate care [18]. Finally, multiple cardiac biomarker measuring strategies have been proposed as tools to improve the sensitivity and specificity of conventional diagnostic and predictive models, and serial measurements of circulating cardiac biomarkers have been used in clinical practice. The current recommendations of the ESC and American Heart Association seriously differentiate in this setting [19]. The aim of the narrative review is to update the current knowledge on the differential choice of circulating cardiac biomarkers in patients with prediabetes and established T2DM. This article is based on previously conducted studies and does not involve any studies with human participants or animals performed by any of the authors. 


\section{TYPE 2 DIABETES MELLITUS AND CV RISK}

$\mathrm{CV}$ risk in T2DM patients is caused by several mechanisms that are associated with the development of micro- and macrovascular dysfunction, accelerating atherosclerosis, an impaired endogenous repair system, direct cell metabolism impairment, oxidative stress, vascular and systemic inflammation, inadequate immune response, cardiac biomechanical stress, fibrosis, necrosis and apoptosis as well as thrombophilia and aggregation of circulating blood cells [20-25]. In fact, from the early stages of prediabetes, traditional CV risk factors (hypertension, smoking, obesity and dyslipidemia) are present in T2DM patients and have an association with $\mathrm{CV}$ death in the diabetic population [24, 25]. Not all cases of HF resulting from the progression of T2DM are associated with primary diabetes-induced metabolic impairments and ventricular hypertrophy [26-28].

T2DM patients have increased mortality and CV complications with a $>4$-fold risk of death and CV among patients without T2DM [29]. However, there are differences in the all-cause mortality and $\mathrm{CV}$ death rates between T2DM patients and non-T2DM patients, and preventive and treatment approaches have been implemented over the last decade [20]. Additionally, the all-cause mortality rate among diabetics, as compared with that in the general population, is influenced by older age, poor glycemic control and renal complications, but these factors are not independently related to death due to CV disease and HF [29]. In this context, biomarkers reflecting CV risk appear to be promising for risk stratification and probably improve point of care in diabetics with unknown $\mathrm{CV}$ disease.

\section{CARDIAC BIOMARKERS IN T2DM}

Evidence shows that conventional $\mathrm{CV}$ risk factors have a negative influence on the mortality rate and quality of life of T2DM patients, and it is suggested that cardiac biomarkers reflecting various pathophysiologic stages of cardiac remodeling, such as biomechanical stress, inflammation, necrosis/apoptosis, fibrosis, hypertrophy and extracellular matrix remodeling, would have an incremental add-on value for the prediction of clinical outcomes (death, MACEs, hospital admission, HF onset) in the patient population. Moreover, measurement of circulating levels of cardiac biomarkers can demonstrate new individual predictive information that could have great predictive power beyond conventional CV risk factors. However, each biomarker has strengths and weaknesses, which affect the cost, specificity, sensitivity, predictive value and superiority in a face-to-face comparison. Because there are numerous circulating biomarkers with unconfirmed abilities to predict clinical outcomes in pre-DM and DM individuals, we here report on cardiac biomarkers whose prognostication value has been established and are still being studied. The utility of circulating cardiac biomarkers in patients with T2DM is reported in Table 1.

\section{Natriuretic Peptides}

Natriuretic peptides have immense systemic homeostatic effects, playing a pivotal role in the regulation of natriuresis, electrolyte and water retention, vascular permeability and vasodilation, cardiac contractility and blood pressure changes; consequently, NPs are physiologic antagonists of the renin-angiotensin-aldosterone and sympatho-adrenal systems [30]. Several types of NPs are released predominantly from the myocardium, atrial (ANP) and brain (BNP) NPs, and vessels, bone and brain (C-type NP) [31]. Physiologic effects of NPs cause binding to the extracellular domains of the appropriate receptors, NPR-A, NPR-B and NPR-C. NPR-A and NPR-C are widely expressed on the surfaces of target cells and involved in the regulation of NP bioavailability independently from circulating neprilysin activity [32]. Synthesis and secretion of NPs, predominantly ANP and BNP, are carried out in response to myocardial stretching and fluid overload, while several stimuli have direct and indirect impacts on NP production, accumulation and secretion, such as ischemia/hypoxia, inflammation, 
Table 1 Utility of circulating cardiac biomarkers in patients with prediabetes and T2DM

\begin{tabular}{|c|c|c|c|}
\hline $\begin{array}{l}\text { Pathogenetic } \\
\text { condition }\end{array}$ & Biomarkers & $\begin{array}{l}\text { Relation to CV risk in patients with } \\
\text { prediabetes and T2DM }\end{array}$ & References \\
\hline \multirow{5}{*}{$\begin{array}{l}\text { Cardiac } \\
\text { biomechanical } \\
\text { stress }\end{array}$} & \multirow[t]{5}{*}{$\begin{array}{l}\text { NPs (atrial NP, NT-proANP, } \\
\text { brain NP, NT-proBNP) }\end{array}$} & $\begin{array}{l}\text { Independent predictors of new-onset CAD, } \\
\text { and MACE }\end{array}$ & {$[46,48,53,63]$} \\
\hline & & Independent predictors of $\mathrm{HF}$ & {$[49,51,54]$} \\
\hline & & $\begin{array}{l}\text { Independent predictors of AF and sudden } \\
\text { death }\end{array}$ & {$[52]$} \\
\hline & & Micro- and macrovascular complications & {$[53,57,58,63]$} \\
\hline & & Predictors of adverse cardiac remodeling & {$[55]$} \\
\hline \multirow{7}{*}{$\begin{array}{l}\text { Cardiac myocyte } \\
\text { necrosis }\end{array}$} & \multirow[t]{4}{*}{ hs-Tn I/T } & Independent predictors of MACE & {$[46,74,84,87]$} \\
\hline & & Predictors of $\mathrm{CV}$ death and $\mathrm{HF}$ & {$[70,73,81]$} \\
\hline & & Predictors of T2DM-induced CMP & {$[81,87]$} \\
\hline & & Predictors of renal outcomes & {$[85,86]$} \\
\hline & \multirow[t]{3}{*}{ H-FABR } & $\begin{array}{l}\text { Predictors of long-term mortality and re- } \\
\text { infarction }\end{array}$ & {$[95]$} \\
\hline & & Predictor of premature death & [99] \\
\hline & & Predictor of asymptomatic cardiac ischemia & {$[101-103]$} \\
\hline \multirow[t]{8}{*}{ Inflammation } & \multirow[t]{3}{*}{ sST2 } & Predictor of CV disease and CV mortality & [111] \\
\hline & & Predictor of HF and HF-related outcomes & {$[110]$} \\
\hline & & Predictor of CV risk and mortality & {$[113-117]$} \\
\hline & \multirow[t]{5}{*}{ GDF15 } & Prediction of CV risk and mortality & {$[124,138]$} \\
\hline & & Prediction of new-onset T2DM & {$[125,127]$} \\
\hline & & Prediction of MACEs in ACS/MI & {$[131,132]$} \\
\hline & & Prediction of HF and HF-related outcomes & {$[133,134,137]$} \\
\hline & & Prediction of T2DM-induced CMP & [139] \\
\hline \multirow[t]{2}{*}{ Fibrosis } & \multirow[t]{2}{*}{ Galectin-3 } & Prediction of T2DM-induced CMP & {$[155]$} \\
\hline & & Prediction of MACEs and all-cause mortality & {$[156,157]$} \\
\hline $\begin{array}{l}\text { Myocardial } \\
\text { hypertrophy }\end{array}$ & Cardiotrophin-1 & Prediction of T2DM-induced CMP & {$[173,174]$} \\
\hline $\begin{array}{l}\text { Extracellular } \\
\text { matrix } \\
\text { remodeling }\end{array}$ & Extracellular matrix biomarkers & $\begin{array}{l}\text { Prediction of HFpEF, HF-related outcomes, } \\
\text { MACEs }\end{array}$ & {$[175-180]$} \\
\hline
\end{tabular}

NPs natriuretic peptides, $s S T 2$ soluble suppressor tumorogenicity-2, CAD coronary artery disease, GDF15 growth/differential factor-15, $A C S$ acute coronary syndrome, $M I$ myocardial infarction, $M A C E$ major adverse cardiac events, $C M P$ cardiomyopathy 
hormones (catecholamines, aldosterone, renin) and growth factors (transforming growth factorbeta, vascular endothelial growth factor) [33]. The C-type NP is a locally produced peptide, which acts as an autocrine regulator of vascular function, bone ossification and development of the nervous system.

Additionally, NPs suppress the lipolytic activity of adipocytes through attenuation of adipose tissue-expressed NPR-A and NPR-C [34]. Nevertheless, NPs increasing p38 MAP kinase in brown adipose tissue cells cause overexpression of "browning" genes ensuring upregulation of energy expenditure and adaptive thermogenesis [35]. NPs are involved in transcriptional regulation of genes, which are responsible for mitochondrial biogenesis, uncoupled respiration (PPAR $\gamma$ coactivator- $1 \alpha$ and uncoupling protein 1), lipid oxidation, GLUT-4 synthesis and insulin sensitivity in various human cells, including adipocytes, skeletal muscle cell, myocardium, vasculature smooth muscle cells, endothelial cells and hepatocytes [36, 37]. In fact, the NPR-A signaling pathway in skeletal muscle cells and hepatocytes is crucial for the metabolic memory phenomenon and the change of pre-diabetes to T2DM [38, 39].

Previous observational and clinical studies have yielded evidence of altered clearance of NPs and impaired activity of neprilysin in patients with abdominal obesity, metabolic syndrome and T2DM in connection with fasting glucose impairment and insulin resistance $[40,41]$. However, there are controversial findings related to the ability of circulating insulin to reciprocally regulate NPR-C expression on the surface of adipose tissue cells in obese individuals [42-44]. Therefore, patients with diabetes-induced nephropathy had increased circulating levels of BNP and NT-pro-BNP compared with those who did not have diabetes renal disease [45]. Overall, the primary cause of the fluctuation of circulating NP levels among patents with metabolic disease is not clear.

Current clinical guidelines recommend measuring NP levels to diagnose HF, stratify patients at higher $\mathrm{CV}$ risk including $\mathrm{HF}$ onset risk and predict short-term re-admission to the hospital because of HF decompensation $[46,47]$. Asymptomatic and symptomatic HF patients can be stratified as at risk of death from any cause and CV disease if they have high circulating levels of NT-proBNP $>125 \mathrm{pg} / \mathrm{ml}$ or $>300 \mathrm{pg} / \mathrm{ml}$, respectively [47]. In fact, increased age was associated with diagnostic cutoff points for the above-mentioned NTproBNP upper values $[45,48]$. Surprisingly, HF patients without T2DM with higher levels of NPs have shown much more predictive accuracy for MACEs, CV mortality and HF manifestation than those who have T2DM $[46,49]$.

Interestingly, women with HF with a preserved ejection fraction (HFpEF) had higher levels of NT-proBNP and consequently CV mortality risk than males with HFpEF [50]. HFpEF patients with T2DM had more ventricular hypertrophy and adverse cardiac remodeling compared with non-T2DM patients, while systolic and diastolic myocardial function and serum levels of NT-proBNP did not differ [51]. There is evidence of NPs in HF in reduced ejection fraction (HFrEF) patients with prediabetes/ T2DM independently predicting atherosclerosis, atrial fibrillation, pulmonary hypertension and sudden death [52-54]. Overall, the NTproBNP level predicted cardiac abnormalities and $\mathrm{CV}$ events regardless of glucose status, and multiple biomarker models are required to improve the predictive accuracy for HF [53-57].

\section{Controversies Related to the Predictive Value of NP in Pre-Diabetics and Diabetics}

There are some controversies related to the variability of predictive values of NPs in patients with abdominal obesity, metabolic syndrome and T2DM. NPs are similar to cardiac troponins in the prediction of micro- and macrovascular complications in pre-diabetics without known $\mathrm{CV}$ disease [58]. Among dysmetabolic patients with HF, adipocytokines (adiponectin, resistin, chemerin, leptin, visfatin) have exhibited additive discriminative power to NT-proBNP for MACEs regardless of glucose status [59-61].

There is a close inverse association between the number of metabolic syndrome components and circulating levels of NPs in middleaged and elderly individuals, but not among young people without CV disease [62]. Overall, 
NPs better predict CV outcomes in patients with known HF than among individuals without HF independently of prediabetes and T2DM [63].

\section{NPs in HFrEF Patients with Prediabetes and DM}

It had been noted that HFrEF patients with prediabetes and T2DM treated with glucagonlike peptide-1 [GLP-1] analog (liraglutide) [64] and sodium-glucose co-transporter-2 [SGLT2] inhibitor (empagliflozine, dapaglyflozine) $[65,66]$ with benefits in CV outcomes have demonstrated a decrease in serum levels of NTproBNP. In contrast, among non-HF patients with prediabetes/T2DM, serum levels of NTproBNP remain unaltered despite improved glucose homeostasis and decreased CV risk [67]. Interestingly, the change in NT-proBNP serum levels correlated negatively with baseline levels of NT-proBNP in T2DM patients [68]. Additionally, in the DEFINE-HF Trial, the SGLT2 inhibitor dapagliflozin did not affect the mean NT-proBNP serum levels, but increased the proportion of patients (diabetics and non-diabetics) experiencing clinically meaningful improvements in HFrEF-related clinical status [69]. These facts require elucidation in large clinical studies in the future.

Overall, NPs continue to be the most important tool for identifying pre-diabetics and diabetics at $\mathrm{CV}$ risk that are affordable. The highest sensitivity and specificity were established for patients with HF symptoms, but for asymptomatic individuals the predictive accuracy of NP levels is superior to traditional CV risk factors. Probably the use of serial measurements of circulating levels of NPs in DM patients with HF treated with SGLT2 inhibitors can be disputed as surrogate markers with possible predictive value.

\section{Cardiac Troponins}

Cardiac troponins are established biomarkers of myocardial injury and necrosis, and, even below the 99th percentile, they strongly predict adverse outcomes in prediabetes and T2DM patients. There is evidence showing that patients with prediabetes and T2DM may develop asymptomatic myocardial damage beyond obvious ischemic causes [70, 71]. The primary causes that lead to increased permeability of cell membranes, leakage of a cytoplasmic pool of cardiac troponins and onset of small-sized myocardial necrosis in prediabetes and diabetes patients are lipotoxicity and myocardial steatosis, which influence the biomechanical myocardial stress, low-grade inflammation, oxidative stress, endoplasmic reticulum stress and mitochondrial stress, altered reparation due to the metabolic memory phenomenon and impaired intracellular metabolism [71, 72].

Micro- and macro-vasculopathies in prediabetes and diabetes are associated with accelerating atherosclerosis, plaque shaping, development of endothelial dysfunction and microvascular obstruction, which induce diabetes-related cardiomyopathy [72, 73]. However, a T2DM-induced significant decrease in sirtuin- 1 and hypoxia-inducible factor (HIF)- $1 \alpha$ expression in the myocardium as well as declining circulating levels of orexin B may contribute to ischemia-reperfusion injury and exacerbate the cardiac and vascular dysfunctions [74].

Therefore, there are extra-cardiac causes that increase high-sensitivity circulating troponin (hs-cTn) T/I levels. For instance, the lowered estimated glomerular filtration rate (per each $15 \mathrm{ml} / \mathrm{min} / 1.73 \mathrm{~m}^{2}$ lower) showed an independent association with a steeper hs-cTnT increase [75]. All of these conditions yield an increased risk of $\mathrm{CV}$ death and $\mathrm{CV}$ events including MACEs and HF [46, 76, 77].

Patients with metabolic syndrome have demonstrated higher hs-cTnI levels than those who do not have the condition, but there were no significant differences in BNP serum levels [78]. Additionally, the levels of hs-cTnI significantly correspond to the presence and components of metabolic syndrome [78]. No significant difference was found in changes in hs-cTnT/I between non-ST elevation myocardial infarction patients with and without T2DM $[79,80]$. However, elevated hs-Tnl levels were found to be independent predictors of MACE in individuals with known CAD regardless of 
glucose metabolism status $[46,79,81,82]$ as well as among patients with prediabetes and T2DM without known CAD [83, 84]. Interestingly, in several large clinical trials, such as SAVOR-TIMI 53 and TECOS, elevated levels of hs-cTnT in patients with T2DM during treatment with antidiabetic drugs (inhibitors of dipeptidyl peptidase 4 saxagliptin and sitagliptin) were significantly associated with renal outcomes rather than $\mathrm{CV}$ events and MACEs $[85,86]$, but in diabetics with $\mathrm{CV}$ disease, i.e., myocardial infarction, the hs-cTnT levels corresponded positively to $\mathrm{CV}$ death, MACEs and HF [87].

Considering the high availability of troponin measurements, affordability of the test and relatively high sensitivity and specificity for prediction of CV events, hs-cTnT/Is are promising for risk stratification of patients with pre-DM and DM with known CV diseases.

\section{Heart-Type Fatty Acid-Binding Protein}

Heart-type fatty acid-binding protein (H-FABR) is a novel serum biomarker of early myocardial ischemia and injury that has been recently reported to be related to CV diseases [88], acute myocardial infarction (MI) $[89,90]$ and longterm post-MI prognosis [91]. H-FABR is rapidly released into the circulation from cardiac myocytes after non-selective increased cell membrane permeability and myocardial injury [89]. H-FABR is more sensitive than conventional biomarkers (myoglobin and hs-cTnT/I) to diagnose acute MI [90]. Circulating levels of H-FABP were also found to be higher in prediabetes [92-94] and T2DM patients [95, 96] than in those who did not have DM. Although H-FABP levels predicted subclinical myocardial injury or subclinical atherosclerosis in patients with prediabetes and T2DM $[97,98]$, its predictive value for $\mathrm{CV}$ risk in patients with impaired glucose metabolism without established CAD is unclear. It has been suggested that higher H-FABP levels in asymptomatic patients at the early stages of metabolic disorders may reflect silent myocardial damage and susceptibility to HF development and the risk of premature cardiac death [99]. This evidence reflects the fact that overexpressed H-FABP in the sub-intima can induce multiple pathways of inflammation, growth and migration of vascular smooth muscle cells and thereby influence in-stent restenosis in the culprit coronary artery after percutaneous coronary intervention (PCI) [100]. Unfortunately, circulating H-FABP levels were found to be similar in T2DM patients without CAD and non-T2DM individuals [101]. Moreover, H-FABP was not a better independent powerful diagnostic biomarker when used alone than traditional CV risk factors [101, 102]. In fact, the strength of the biomarker is its ability to diagnose the early period of asymptomatic cardiac ischemia in T2DM patients with diabetic ketoacidosis and diabetic ketosis, and it is also inexpensive [103]. Large clinical trials are required to identify the predictive ability of the biomarker in a face-to-face comparison with other biomarkers in prediabetes and DM patients.

\section{Soluble Suppressor Tumorogenisity-2}

The soluble form of suppressor tumorogenisity2 (sST2) acts as a decoy receptor of interleukin (IL)-33, inhibiting the effects of IL-33/ST2 ligand signaling, and it is produced by endothelial and epithelial cells, fibroblasts and certain immune cells in response to biomechanical stress, ischemia/necrosis, hypoxia and inflammatory cytokines [104]. In fact, the IL-33/ ST2/sST2 axis is a core component of the autocrine/paracrine mechanism acting to prevent tissue injury [105, 106].

Elevated levels of sST2 were not found to be a specific diagnostic biomarker for a single disorder in humans, but increased serum concentrations of sST2 were linked to the progression of atherosclerosis [107], myocardial dysfunction [108], fibrosis and adverse cardiac remodeling [109], poor clinical outcomes in CV diseases including $\mathrm{HF}$ and atrial fibrillation [110] and metabolic disorders including diabetes mellitus and metabolic syndrome [111]. In fact, serum sST2 was measured in higher concentrations in T2DM patients, and the presence of left ventricular hypertrophy and diastolic and systolic cardiac dysfunction was associated with even 
higher sST2 levels [108]. sST2 has been validated as a predictive biomarker for $\mathrm{CV}$ disease and $\mathrm{CV}$ events, including HF [48]. Therefore, sST2 independently predicted the no-reflow phenomenon in STEMI patients undergoing primary PCI [112].

Previous clinical studies have shown that sST2 levels are strongly associated with several markers of T2DM including glycosylated hemoglobin, triglyceride levels, fasting glucose, HOMA-IR, ectopic fat accumulation and the glomerular filtration rate, and the levels in women are lower than in men, but the SST2 concentration increases with age $[113,114]$. Elevated levels of sST2 are not an independent predictor of mortality and MACE in diabetics with acute coronary syndrome (ACS) and MI [115], whereas in ACS/MI patients without T2DM elevated levels of sST2 are independently associated with a risk of early in-hospital death, 30-day death and HF onset [116, 117].

Thus, most investigations have shown that sST2 levels are higher in patients with CV disease who also have either prediabetes or T2DM and that this association has independent predictive value for prognosis. The weakness of this biomarker is that that associations between serum levels of sST2 and other CV biomarkers (including NPs) and CV-related events in dysmetabolic individuals without $\mathrm{CV}$ disease have not been carefully studied, and the predictive power of sST2 beyond conventional CV risk factors requires confirmation in the future.

\section{Growth Differentiation Factor 15}

Growth differentiation factor 15 (GDF15), also known as macrophage-inhibiting cytokine 1 , belongs to the transforming growth factor- $B$ (TGF-ß) superfamily [118]. GDF15 is released from a wide range of cells, such as mononuclear cells, macrophages, cardiac myocytes and adipocytes, under inflammatory conditions and oxidative stress $[119,120]$. The main biologic role of the GDF15 is to regulate the inflammatory response, growth, cell differentiation, energy homoeostasis and weight loss. In fact, GDF-15 protects target tissues (myocardium, kidney, adipose tissue and vasculature) by several intracellular molecular pathways, such as inhibiting c-Jun N-terminal kinase, Bcl-2-associated death promoter, epidermal growth factor receptor and activating SMAD, endothelial NO synthase and phosphoinositide 3-kinase/AKT signaling pathways [121]. There is evidence of a role of GDF15 in oxidative stress, protein glycation, inflammation, cellular senescence and hormonal deregulation in aging and age-depending diseases [122, 123].

Serum levels of GDF15 were found to be higher in prediabetes/T2DM patients than in healthy volunteers and independently associated with CV risk scores [124], body mass index, waist-to-hip ratio [125], insulin resistance [126], hs-CRP [127] and parameters of glucose metabolism (C-peptide, fasting pre-hepatic beta cell function, impaired fasting glucose) [128, 129], while successful glycemic control did not cause a decrease in GDF15 levels [130].

Previous clinical studies have shown elevated levels of GDF15 are independently related to adverse cardiac remodeling and poor prognosis in ACS/MI [131, 132], HF [133], atrial fibrillation [134], renal dysfunction [135] and cachexia $[135,136]$. Moreover, serial measurements of GDF15 have shown that an increase in GDF-15 over 1 year was independently associated with higher risks of future $\mathrm{CV}$ mortality beyond the NYHA functional class, left ventricular (LV) ejection fraction (EF) and circulating levels of NT-proBNP [137]. Additionally, elevated levels of GDF15 were strongly associated with an increase of the all-cause mortality rate in patients with atherosclerosis, such as angiographically proven CAD and peripheral artery disease, regardless of T2DM presentation [138].

Interestingly, elevated levels of the GDF15 over the cutoff point of $3812 \mathrm{pg} / \mathrm{ml}$ predicted T2DM-induced cardiomyopathy in the absence of other CV risk factors, such as age, smoking, hypertension and known CV disease [139]. Moreover, some antidiabetic drugs, such as metformin, promote their cardioprotective effects through GDF15 expression in target tissue [140]. Having strong evidence that GDF15 expression in multiple tissues is higher in prediabetes and T2DM patients than in individuals without metabolic disorders [141, 142], it has been suggested that GDF-15 may be a promising 
biomarker for identification of people at risk of metabolic-induced events (T2DM-induced cardiomyopathy) and CV disease/events. It can be of great clinical importance because a highly anticipated new class of GFRAL (receptor for GDF15)/RET (receptor tyrosine kinase)-based drugs for the treatment of abdominal obesity and metabolic syndrome may mediate the endogenous effects of GDF15 and thereby improve $\mathrm{CV}$ risk in individuals with metabolic diseases [143, 144].

\section{Galectin-3}

Galectin-3 (Gal-3) is a versatile protein that belongs to the lectin family and has been implicated predominantly in cardiac, liver and kidney fibrosis and inflammation [145, 146]. Overexpression of Gal-3 is associated with accumulation of advanced glycation end products (AGE), oxidative stress products (3-nitrotyrosine protein, superoxide radicals) and activation of the pro-apoptotic c-Jun-N-terminal kinase $1 / 2$ stress signaling pathway, which directly influences the development of endothelial dysfunction and altered vascular reparation [147, 148].

Mediating profibrotic pathways, Gal-3 predicts cardiac remodeling and CV events that are independently related to it, such as $\mathrm{HF}$ and atrial fibrillation [149, 150]. Among asymptomatic adults from the general population, the highest quartile of Gal-3 levels was closely associated with two-fold increased odds of myocardial dysfunction compared with the lowest quartile of the biomarker [151]. Additionally, elevated levels of GDF15 were related to methylated arginine and hs-CRP in patients with prediabetes and T2DM without known CAD [152].

Based on previous clinical studies, Gal-3 has served as a prognostic clinical biomarker in HF [48], but its role in the prediction of T2DM was uncertain until the end of the Dallas Heart Study [153]. Gal-3 levels in the trial were associated with the incidence of T2DM even after adjustment for conventional metabolic and CV risk factors (age, gender, race, body mass index and hypertension) and renal function.
Therefore, there were correlations between Gal3 levels and circulating levels of inflammatory biomarkers (hs-CRP, IL-18, monocyte chemoattractant protein 1, soluble tumor necrosis factor receptor 1-alpha and myeloperoxidase), insulin secretion biomarkers (C-peptide), the homeostatic model assessment for insulin resistance and subcutaneous adiposity. Interestingly, in patients with abdominal obesity and prediabetes without established CAD, increased levels of the GDF15 were correlated with LV diastolic dysfunction and elevated pulmonary artery systolic pressure, but not with LV mass [154]. Elevated Gal-3 levels were associated with diminished global longitudinal strain in diabetics [155]. There is confirmation of a close association between elevated levels of GDF15 in prediabetic individuals and patients with T2DM and a risk of vascular calcification, plaque formation and endothelial dysfunction, corresponding to a risk of MACEs and all-cause mortality [156-158].

There are data elucidating the possible interrelation between dynamic changes in circulating levels of GDF15 and CV risk in T2DM patients treated with antidiabetic drugs $[159,160]$. Serum Gal-3 levels in T2DM patients showed a modest increase from the baseline with the SGLT2 inhibitor canagliflozin versus placebo, whereas the concentrations of both NT-proBNP and hs-cTnI for $>2$ years have demonstrated a tendency to decrease [161]. Large clinical trials are required to elucidate a strategy for GDF15-guided therapy of T2DM without $\mathrm{CV}$ disease and with established $\mathrm{CV}$ disease including HF. Finally, Gal-3 is a promising biomarker with high sensitivity and specificity that identifies preclinical metabolic heart disease and stratifies patients at risk of $\mathrm{CV}$ death and CV events including HF. The economic aspect of using this biomarker requires further elucidated.

\section{Cardiotrophin-1}

Cardiotrophin-1 (CT-1) is an adipocytokine that belongs to the IL- 6 family and realizes its biologic effect by binding to the gp130 receptor [162]. CT-1 and its receptors are expressed in 
many tissues including the myocardium, brain, kidney, skeletal muscles, adipose tissue, liver, lung and testes and acts as an endocrine and paracrine regulator of physiologic and pathophysiologic functions [163]. The main source of CT synthesis is adipocytes, and down- and upregulated CT-1 gene expressions were found in white and subcutaneous adipose tissue, respectively [164, 165]. CT-1 decreases fasting glucose in an insulin-independent manner, mediates increased insulin sensitivity through the AKT-dependent pathway in skeletal muscles, reduces food intake, stimulates lipolysis and enhances energy expenditure [166].

It has been suggested that in patients with abdominal obesity, metabolic syndrome and T2DM adipose-derived CT-1 ensure metabolic circadian rhythms and adipose core clock genes [167] and promote tissue-protective effects including increased resistance of cardiac myocytes to hypoxia/ischemia, growth and differentiation of progenitor cells of different origin, reducing $[163,168]$. Indeed, lowered circulating levels of CT-1 were associated with decreased risk of metabolic syndrome and T2DM in overweight patients [169]. Moreover, the CT-1 level was inversely correlated with the severity of obesity in non-T2DM patients [170].

A large body of evidence shows that the changes in LV geometry and development of LV hypertrophy and systolic and diastolic HF are related to lowered expression of CT- 1 receptors in the heart and increased circulating levels of CT-1 in the peripheral blood [171, 172]. Additionally, the circulating level of CT-1 predicts the risk of T2DM manifestation, T2DM-induced target organ damage and $\mathrm{CV}$ complications regardless of classic CV risk factors [173, 174]. Although CT-1 has possible predictive ability for LV hypertrophy, T2DM-induced cardiomyopathy and HF appear to be promising; large clinical trials are required to ascertain whether this biomarker has independent discriminative power and is affordable to use in a face-to-face comparison with other outcome indicators.

\section{Future Biomarkers}

\section{Collagen Turnover Biomarkers}

There is a wide spectrum of biomarkers, which reflects several stages of TDM pathogenesis and could predict CV risk. For instance, carboxyterminal telopeptide of collagen type 1 was measured in elevated concentrations in peripheral blood among diabetics compared with healthy volunteers and individuals with metabolically healthy obesity [51]. This is a profibrotic biomarker with predictive value for $\mathrm{CV}$ events that also is found in elevated levels in patients with HFpEF [175].

Other collagen biomarkers, such as procollagen type III N-terminal propeptide and collagen type I carboxy-terminal telopeptide, also appeared to be related to incident HFpEF, but not HFrEF [176]. Whether these pro-peptides, which reflect collagen synthesis and degradation, can be used to prognosticate $\mathrm{CV}$ risk in patients with metabolic disease is not fully understood, but a growing body of evidence suggests that they may play a pivotal role in point of care in patients with HFpEF and possibly HFrEF regardless of glucose impairment [177].

\section{Biomarkers of Extracellular Matrix Remodeling}

Extracellular matrix remodeling biomarkers, such as matrix metalloproteinase (MMP)-1, MMP-6 and MMP-9, and their tissue inhibitors, osteoprotegerin and osteopontin, are promising indicators of adverse cardiac remodeling and MACEs in the post-MI period, but they are not specific to T2DM-induced cardiac damage and correspond well to conventional CV risk factors including chronic kidney disease, aging and hypertension [178-180].

\section{Apelin}

Another promising biomarker for LV hypertrophy and HF is apelin, which has demonstrated vasodilator, inotropic and aquaretic properties and is a physiologic antagonist of RAAS $[181,182]$. It has been shown that the development of DM-induced cardiomyopathy is attenuated by preventing mitochondrial 
dysfunction through the Apelin/Sirt3 pathway [183]. The predictive role of apelin in the Apelin/Sirt3 pathway for HF in DM patients is under investigation.

\section{Non-Coding RNAs}

Non-coding RNAs, including microRNAs (miRNAs), as well-established powerful regulators of posttranscriptional gene expression, could be potential biomarkers for $\mathrm{CV}$ risk in patients with prediabetes and DM [184]. Although there are organ-specific miRNAs, expression of which are highly up- or downregulated in HF, there are no clear advantages to the signature of circulating cell-free miRNAs and microvesiclederived miRNAs compared with traditional CV risk biomarkers and HF biomarkers [185].

\section{CONCLUSIONS}

Although conventional cardiac biomarkers, such as NPs, sST2, cardiac troponins and galectin-3, can be useful for ascertaining CV risk in patients with prediabetes and T2DM, there are confusing reports regarding their ability to be prognostically relevant among patients without known CV disease. There have been many cohort clinical studies with small sample sizes in which the higher predictive power of these biomarkers for CV death and MACEs in patients with metabolic diseases was determined, but large clinical trials have not demonstrated significant results in this context. This is perhaps related to mixed patient cohorts (having and not having CV diseases) enrolled in the studies for which positive predictive values of biomarkers were sufficiently distinguished. Another cause is the significant difference in the quality of the studies. Therefore, numerous results were obtained from post hoc data analyses, and they were not given during prospective observation even when a large sample size was presented. Most positive findings regarding independent prediction of $\mathrm{CV}$ death, MACEs and $\mathrm{HF}$ in prediabetes and T2DM populations were obtained for NPs and hs-cTn I/T, whereas other cardiac biomarkers did not frequently show independent power in individuals without known CV disease. These discrepancies urged investigations of new biomarkers, such as GDF15, H-FABR, CT-1, carboxy-terminal telopeptide of collagen type 1 , apelin and miRNAs as well as multiple biomarker predictive scores. Finally, NPs and hs-cTnT continue to be the most important tools with an affordable price as well as high sensitivity and specificity to predict clinical outcomes among patients with pre-DM and DM in routine clinical practice, but other circulating biomarkers need to be carefully investigated in large trials in the future.

\section{ACKNOWLEDGEMENTS}

Funding. This research received no specific grant from any funding agency in the public, commercial or not-for-profit sectors. No Rapid Service Fee was received by the journal for the publication of this article.

Authorship. All named authors meet the International Committee of Medical Journal Editors (ICMJE) criteria for authorship for this article, take responsibility for the integrity of the work as a whole and have given their approval for this version to be published.

Authorship Contributions. All authors contributed equally to the literature search, review design, data collection and analysis, interpretation and writing of the paper.

Disclosures. Alexander E. Berezin and Alexander A. Berezin have nothing to disclose.

Compliance with Ethics Guidelines. This article is based on previously conducted studies and does not contain any studies with human participants or animals performed by any of the authors.

Data Availability. Data sharing is not applicable to this article as no datasets were generated or analyzed during the current study.

Open Access. This article is licensed under a Creative Commons Attribution-NonCommercial 4.0 International License, which permits 
any non-commercial use, sharing, adaptation, distribution and reproduction in any medium or format, as long as you give appropriate credit to the original author(s) and the source, provide a link to the Creative Commons licence, and indicate if changes were made. The images or other third party material in this article are included in the article's Creative Commons licence, unless indicated otherwise in a credit line to the material. If material is not included in the article's Creative Commons licence and your intended use is not permitted by statutory regulation or exceeds the permitted use, you will need to obtain permission directly from the copyright holder. To view a copy of this licence, visit http://creativecommons.org/licenses/by$\mathrm{nc} / 4.0 /$.

\section{REFERENCES}

1. Benjamin EJ, Virani SS, Callaway CW, Chamberlain AM, Chang AR, Cheng S, et al. Heart disease and stroke statistics-2018 update: a report from the American Heart Association. Circulation. 2018;137: e67-492. 0000000000000558 .

2. Tao Z, Shi A, Zhao J. Epidemiological perspectives of diabetes. Cell Biochem Biophys. 2015;73(1):181-5. https://doi.org/10.1007/s12013-015-0598-4.

3. Selvin E, Parrinello CM, Sacks DB, Coresh J. Trends in prevalence and control of diabetes in the United States, 1988-1994 and 1999-2010. Ann Intern Med. 2014;160:517-25. https://doi.org/10.7326/M132411.

4. Cavender MA, Steg PG, Smith SC Jr, Eagle K, Ohman EM, Goto S, REACH Registry Investigators, et al. Impact of Diabetes Mellitus on Hospitalization for Heart Failure, Cardiovascular Events, and Death: Outcomes at 4 Years From the Reduction of Atherothrombosis for Continued Health (REACH) Registry. Circulation. 2015;132(10):923-31. https:// doi.org/10.1161/circulationaha.114.014796.

5. Udell JA, Steg PG, Scirica BM, Eagle KA, Ohman EM, Goto S, Reduction of Atherothrombosis for Continued Health (REACH) Registry Investigators, et al. Metabolic syndrome, diabetes mellitus, or both and cardiovascular risk in outpatients with or at risk for atherothrombosis. Eur J Prev Cardiol. 2014;21(12): $1531-40$. https://doi.org/10.1177/
6. Norhammar A, Malmberg K, Diderholm E, Lagerqvist $\mathrm{B}$, Lindahl B, Rydén L, et al. Diabetes mellitus: the major risk factor in unstable coronary artery disease even after consideration of the extent of coronary artery disease and benefits of revascularization. J Am Coll Cardiol. 2004;43:585-91. https:// doi.org/10.1016/j.jacc.2003.08.050.

7. Yang GR, Dye TD, Li D. Association between diabetes, metabolic syndrome and heart attack in US adults: a cross-sectional analysis using the Behavioral Risk Factor Surveillance System 2015. BMJ Open. 2019;9(9):e022990. https://doi.org/10.1136/ bmjopen-2018-022990.

8. Bae JC, Cho NH, Suh S, Kim JH, Hur KY, Jin SM, et al. Cardiovascular disease incidence, mortality and case fatality related to diabetes and metabolic syndrome: a community-based prospective study (Ansung-Ansan cohort 2001-12). J Diabetes. 2015;7: 791-9. https://doi.org/10.1111/1753-0407.12248.

9. Udell JA, Steg PG, Scirica BM, Eagle KA, Ohman EM, Goto S, Reduction of Atherothrombosis for Continued Health (REACH) Registry Investigators, et al. Metabolic syndrome, diabetes mellitus, or both and cardiovascular risk in outpatients with or at risk for atherothrombosis. Eur J Prev Cardiol. 2014;21: 1531-40. https://doi.org/10.1177/ 2047487313500541.

10. Church TS, Thompson AM, Katzmarzyk PT, Sui X, Johannsen N, Earnest CP, et al. Metabolic syndrome and diabetes, alone and in combination, as predictors of cardiovascular disease mortality among men. Diabetes Care. 2009;32:1289-94. https://doi.org/10. 2337/dc08-1871.

11. Juutilainen A, Lehto S, Rönnemaa T, Pyörälä K, Laakso M. Proteinuria and metabolic syndrome as predictors of cardiovascular death in non-diabetic and type 2 diabetic men and women. Diabetologia. 2006;49(1):56-65.

12. Berezin AE. Biomarkers for cardiovascular risk in patients with diabetes. Heart. 2016;102(24): 1939-41. https://doi.org/10.1136/heartjnl-2016310197.

13. Cosentino F, Grant PJ, Aboyans V, Bailey CJ, Ceriello A, Delgado V, ESC Scientific Document Group, et al. ESC Guidelines on diabetes, pre-diabetes, and cardiovascular diseases developed in collaboration with the EASD. Eur Heart J. 2019. https://doi.org/ 10.1093/eurheartj/ehz486.

14. Åkerblom A, Wojdyla D, Steg PG, Wallentin L, James SK, Budaj A, PLATO Investigators, et al. Prevalence and relevance of abnormal glucose metabolism in acute coronary syndromes: insights from the PLATelet inhibition and patient Outcomes (PLATO) trial. J Thromb Thrombolysis. 2019;48(4): 
563-9. https://doi.org/10.1007/s11239-019-019382.

15. Palau P, Bertomeu-González V, Sanchis J, Soler M, de la Espriella R, Domínguez E, et al. Differential prognostic impact of type 2 diabetes mellitus in women and men with heart failure with preserved ejection fraction. Rev Esp Cardiol (Engl Ed). 2019. https://doi.org/10.1016/j.rec.2019.09.002 (Epub ahead of print).

16. Berezin AE. Circulating biomarkers in heart failure. Adv Exp Med Biol. 2018;1067:89-108. https://doi. org/10.1007/5584_2017_140.

17. Wong YK, Cheung CYY, Tang CS, Au KW, Hai JSH, Lee CH, Lau KK, Cheung BMY, Sham PC, Xu A, et al. Age-biomarkers-clinical risk factors for prediction of cardiovascular events in patients with coronary artery disease. Arterioscler Thromb Vasc Biol. 2018;38(10):2519-27. https://doi.org/10.1161/ ATVBAHA.118.311726.

18. Berezin AE. Prognostication of clinical outcomes in diabetes mellitus: emerging role of cardiac biomarkers. Diabetes Metab Syndr. 2019;13(2): 995-1003. https://doi.org/10.1016/j.dsx.2019.01. 018.

19. van der Meer P, Gaggin HK, Dec GW. ACC/AHA versus ESC Guidelines on Heart Failure. J Am Coll Cardiol. 2019;73(21):2756-68.

20. Gregg EW, Cheng YJ, Srinivasan M, Lin J, Geiss LS, Albright AL, et al. Trends in cause-specific mortality among adults with and without diagnosed diabetes in the USA: an epidemiological analysis of linked national survey and vital statistics data. Lancet. 2018;391:2430-40.

21. Yau JW, Rogers SL, Kawasaki R, Lamoureux EL, Kowalski JW, Bek T, et al. Global prevalence and major risk factors of diabetic retinopathy. Diabetes Care. 2012;35:556-64.

22. Hewitt J, Castilla Guerra L, Fernández-Moreno Mdel C, Sierra C. Diabetes and stroke prevention: a review. Stroke Res Treat. 2012;2012:673187.

23. Jee D, Lee WK, Kang S. Prevalence and risk factors for diabetic retinopathy: the Korea National Health and Nutrition Examination Survey 2008-2011. Invest Ophthalmol Vis Sci. 2013;54(10):6827-33. https://doi.org/10.1167/iovs.13-12654.

24. Goraya TY, Leibson CL, Palumbo PJ, Weston SA, Killian JM, Pfeifer EA, et al. Coronary atherosclerosis in diabetes mellitus: a population-based autopsy study. J Am Coll Cardiol. 2002;40:946-53.

25. Thiruvoipati T, Kielhorn CE, Armstrong EJ. Peripheral artery disease in patients with diabetes: epidemiology, mechanisms, and outcomes. World J Diabetes. 2015;6:961-9.

26. Jia G, Hill MA, Sowers JR. Diabetic cardiomyopathy: an update of mechanisms contributing to this clinical entity. Circ Res. 2018;122:624-38.

27. Paulus WJ, Dal Canto E. Distinct myocardial targets for diabetes therapy in heart failure with preserved or reduced ejection fraction. JACC Heart Fail. $2018 ; 6: 1-7$.

28. Ernande L, Audureau E, Jellis CL, Bergerot C, Henegar C, Sawaki D, et al. Clinical implications of echocardiographic phenotypes of patients with diabetes mellitus. J Am Coll Cardiol. 2017;70: 1704-16.

29. Tancredi M, Rosengren A, Svensson AM, Kosiborod M, Pivodic A, Gudbjörnsdottir S, et al. Excess mortality among persons with type 2 diabetes. N Engl J Med. 2015;373:1720-32.

30. Potter LR, Abbey-Hosch S, Dickey DM. Natriuretic peptides, their receptors, and cyclic guanosine monophosphate-dependent signaling functions. Endocr Rev. 2006;27:47-72.

31. Potter LR, Hunter T. Guanylyl cyclase-linked natriuretic peptide receptors: structure and regulation. J Biol Chem. 2001;276:6057-60.

32. Kovacova Z, Tharp WG, Liu D, Wei W, Xie H, Collins $S$, et al. Adipose tissue natriuretic peptide receptor expression is related to insulin sensitivity in obesity and diabetes. Obesity (Silver Spring). 2016;24(4):820-8. https://doi.org/10.1002/oby. 21418.

33. Moro C. Targeting cardiac natriuretic peptides in the therapy of diabetes and obesity. Expert Opin Ther Targets. 2016;20(12):1445-52.

34. Bordicchia M, Ceresiani M, Pavani M, Minardi D, Polito M, Wabitsch M, et al. Insulin/glucose induces natriuretic peptide clearance receptor in human adipocytes: a metabolic link with the cardiac natriuretic pathway. Am J Physiol Regul Integr Comp Physiol. 2016;311(1):R104-14. https://doi.org/10. 1152/ajpregu.00499.2015.

35. Bordicchia M, Liu D, Amri EZ, Ailhaud G, DessìFulgheri P, Zhang C, et al. Cardiac natriuretic peptides act via p38 MAPK to induce the brown fat thermogenic program in mouse and human adipocytes. J Clin Invest. 2012;122:1022-36.

36. Sengenes C, Berlan M, De Glisezinski I, Lafontan M, Galitzky J. Natriuretic peptides: a new lipolytic pathway in human adipocytes. FASEB J. 2000;14: 1345-51. 
37. Engeli S, Birkenfeld AL, Badin PM, Bourlier V, Louche K, Viguerie N, et al. Natriuretic peptides enhance the oxidative capacity of human skeletal muscle. J Clin Invest. 2012;122:4675-9.

38. Coué M, Badin PM, Vila IK, Laurens C, Louche K, Marquès MA, et al. Defective natriuretic peptide receptor signaling in skeletal muscle links obesity to type 2 diabetes. Diabetes. 2015;64(12):4033-45. https://doi.org/10.2337/db15-0305.

39. Højlund K. Metabolism and insulin signaling in common metabolic disorders and inherited insulin resistance. Dan Med J. 2014;61(7):B4890.

40. Chen Y, Burnett JC Jr. Biochemistry, therapeutics, and biomarker implications of neprilysin in cardiorenal disease. Clin Chem. 2017;63(1):108-15. https://doi.org/10.1373/clinchem.2016.262907.

41. Lee KM, Lee MC, Lee CJ, Chen YC, Hsu BG. Inverse association of N-terminal pro-B-type natriuretic peptide level with metabolic syndrome in kidney transplant patients. Transpl Proc. 2018;50(8): 2496-501. https://doi.org/10.1016/j.transproceed. 2018.04.005.

42. Pivovarova O, Gogebakan O, Kloting N, Sparwasser A, Weickert MO, Haddad I, et al. Insulin up-regulates natriuretic peptide clearance receptor expression in the subcutaneous fat depot in obese subjects: a missing link between CVD risk and obesity? J Clin Endocrinol Metab. 2012;97:E731-9.

43. Sarzani R, Salvi F, Dessi-Fulgheri P, Rappelli A. Renin-angiotensin system, natriuretic peptides, obesity, metabolic syndrome, and hypertension: an integrated view in humans. J Hypertens. 2008;26: 831-43.

44. Ahued-Ortega JA, León-García PE, Hernández-Pérez E. Correlation of plasma B-type natriuretic peptide levels with metabolic risk markers. Med Clin (Barc). 2018;151(12):481-6. https://doi.org/10.1016/j. medcli.2018.02.009.

45. Di Marca S, Rando A, Cataudella E, Pulvirenti A, Alaimo S, Terranova V, et al. B-type natriuretic peptide may predict prognosis in older adults admitted with a diagnosis other than heart failure. Nutr Metab Cardiovasc Dis. 2018;28(6):636-42. https://doi.org/10.1016/j.numecd.2018.02.017.

46. Wong YK, Cheung CYY, Tang CS, Hai JSH, Lee CH, Lau KK, et al. High-sensitivity troponin I and B-type natriuretic peptide biomarkers for prediction of cardiovascular events in patients with coronary artery disease with and without diabetes mellitus. Cardiovasc Diabetol. 2019;18(1):171. https://doi. org/10.1186/s12933-019-0974-2.
47. Ponikowski P, Voors AA, Anker SD, Bueno H, Cleland JGF, Coats AJS, ESC Scientific Document Group, et al. ESC guidelines for the diagnosis and treatment of acute and chronic heart failure: the Task Force for the diagnosis and treatment of acute and chronic heart failure of the European Society of Cardiology (ESC) developed with the special contribution of the Heart Failure Association (HFA) of the ESC. Eur Heart J. 2016;2016(37):2129-200.

48. Yancy CW, Jessup M, Bozkurt B, Butler J, Casey DE Jr, Colvin MM, et al. 2017 ACC/AHA/HFSA focused update of the 2013 ACCF/AHA guideline for the management of heart failure: a report of the American College of Cardiology/American Heart Association Task Force on Clinical Practice Guidelines and the Heart Failure Society of America. Circulation. 2017;136(6):137-61.

49. Benomar K, Espiard S, Loyer C, Jannin A, Vantyghem MC. Atrial natriuretic hormones and metabolic syndrome: recent advances. Presse Med. 2018;47(2):116-24. https://doi.org/10.1016/j.lpm. 2017.12.002.

50. Palau P, Bertomeu-González V, Sanchis J, Soler M, de la Espriella R, Domínguez E, et al. Differential prognostic impact of type 2 diabetes mellitus in women and men with heart failure with preserved ejection fraction. Rev Esp Cardiol (Engl Ed). 2019. https://doi.org/10.1016/j.rec.2019.09.002.

51. Lindman BR, Dávila-Román VG, Mann DL, McNulty S, Semigran MJ, Lewis GD, et al. Cardiovascular phenotype in HFpEF patients with or without diabetes: a RELAX trial ancillary study. J Am Coll Cardiol. 2014;64(6):541-9. https://doi. org/10.1016/j.jacc.2014.05.030.

52. Georgakopoulos C, Vlachopoulos C, Lazaros G, Tousoulis D. Biomarkers of atrial fibrillation in metabolic syndrome. Curr Med Chem. 2019;26(5): 898-908. https://doi.org/10.2174/ 0929867324666171012105528.

53. Obaid N, Hadidy SE, Badry ME, Khaled H. The outcome of diabetic patients with cardiomyopathy in critical care unit: hospital and short-term outcome in a period of six months to one year. Open Access Maced J Med Sci. 2019;7(17):2796-801. https://doi.org/10.3889/oamjms.2019.655.

54. Horwich TB, Hamilton MA, Fonarow GC. B-type natriuretic peptide levels in obese patients with advanced heart failure. J Am Coll Cardiol. 2006;47: 85-90.

55. Krzesiński P, Uziebło-Życzkowska B, Gielerak G, Stańczyk A, Piotrowicz K, Piechota W, et al. Echocardiographic assessment and N-terminal probrain natriuretic peptide in hypertensives with metabolic syndrome. Adv Clin Exp Med. 
2017;26(2):295-301. acem/33554.

https://doi.org/10.17219/

56. Mocan M, Anton F, Suciu Ş, Răhăian R, Blaga SN, Fărcaş AD. Multimarker assessment of diastolic dysfunction in metabolic syndrome patients. Metab Syndr Relat Disord. 2017;15(10):507-14.

57. Prickett TCR, Darlow BA, Troughton RW, Cameron VA, Elliott JM, Martin J, et al. New insights into cardiac and vascular natriuretic peptides: findings from young adults born with very low birth weight. Clin Chem. 2018;64(2):363-73. https://doi.org/10. 1373/clinchem.2017.280354.

58. Parsanathan R, Jain SK. Novel invasive and noninvasive cardiac-specific biomarkers in obesity and cardiovascular diseases. Metab Syndr Relat Disord. 2019. https://doi.org/10.1089/met.2019.0073 (Epub ahead of print).

59. Zhou X, Tao Y, Chen Y, Xu W, Qian Z, Lu X. Serum chemerin as a novel prognostic indicator in chronic heart failure. J Am Heart Assoc. 2019;8(15):e012091. https://doi.org/10.1161/JAHA.119.012091.

60. Contaifer D Jr, Buckley LF, Wohlford G, Kumar NG, Morriss JM, Ranasinghe AD, et al. Metabolic modulation predicts heart failure tests performance. PLoS One. 2019;14(6):e0218153. https://doi.org/10. 1371/journal.pone.0218153.

61. Berezin AE, Samura TA, Kremzer AA, Berezina TA, Martovitskaya YV, Gromenko EA. An association of serum visfatin level and number of circulating endothelial progenitor cells in type 2 diabetes mellitus patients. Diabetes Metab Syndr. 2016;10(4): 205-12. https://doi.org/10.1016/j.dsx.2016.06.008.

62. Goharian TS, Goetze JP, Faber J, Andersen LB, Grøntved A, Jeppesen JL. Associations of pro-atrial natriuretic peptide with components of the metabolic syndrome in adolescents and young adults from the general population. Am J Hypertens. 2017;30(6):561-8. https://doi.org/10.1093/ajh/ hpx026.

63. Huang FY, Peng Y, Deng XX, Huang BT, Xia TL, Gui $Y Y$, et al. The influence of metabolic syndrome and diabetes mellitus on the N-terminal pro-B-type natriuretic peptide level and its prognostic performance in patients with coronary artery disease. Coron Artery Dis. 2017;28(2):159-65. https://doi. org/10.1097/MCA.0000000000000464.

64. Nomoto H, Miyoshi H, Furumoto T, Oba K, Tsutsui $\mathrm{H}$, Miyoshi A, et al. A Comparison of the Effects of the GLP-1 Analogue Liraglutide and Insulin Glargine on Endothelial Function and Metabolic Parameters: A Randomized, Controlled Trial Sapporo Athero-Incretin Study 2 (SAIS2). PLoS One. 2015;10(8):e0135854.

journal.pone.0135854.

https://doi.org/10.1371/

65. Verma S, Mazer CD, Yan AT, Mason T, Garg V, Teoh $\mathrm{H}$, et al. Effect of empagliflozin on left ventricular mass in patients with type 2 diabetes mellitus and coronary artery disease: the EMPA-HEART cardiolink-6 randomized clinical trial. Circulation. 2019;140(21):1693-702. https://doi.org/10.1161/ CIRCULATIONAHA.119.042375.

66. Jensen J, Omar M, Kistorp C, Poulsen MK, Tuxen C, Gustafsson I, et al. Empagliflozin in heart failure patients with reduced ejection fraction: a randomized clinical trial (Empire HF). Trials. 2019;20(1): 374. https://doi.org/10.1186/s13063-019-3474-5.

67. Ferrannini E, Baldi S, Frascerra S, Astiarraga B, Barsotti E, Clerico A, et al. Renal handling of ketones in response to sodium-glucose cotransporter 2 inhibition in patients with type 2 diabetes. Diabetes Care. 2017;40(6):771-6. https://doi.org/10.2337/dc162724.

68. Cho KY, Nakamura A, Omori K, Takase T, Miya A, Manda N, et al. Effect of switching from pioglitazone to the sodium glucose co-transporter-2 inhibitor dapagliflozin on body weight and metabolismrelated factors in patients with type 2 diabetes mellitus: an open-label, prospective, randomized, parallel-group comparison trial. Diabetes Obes Metab. 2019;21(3):710-4. https://doi.org/10.1111/ dom.13557.

69. Nassif ME, Windsor SL, Tang F, Khariton Y, Husain $\mathrm{M}$, Inzucchi SE, et al. Dapagliflozin effects on biomarkers, symptoms, and functional status in patients with heart failure with reduced ejection fraction: the DEFINE-HF Trial. Circulation. 2019;140(18):1463-76. https://doi.org/10.1161/ CIRCULATIONAHA.119.042929 Epub 2019 Sep 16.

70. Swoboda PP, McDiarmid AK, Erhayiem B, Ripley DP, Dobson LE, Garg P, et al. Diabetes mellitus, microalbuminuria, and subclinical cardiac disease: identification and monitoring of individuals at risk of heart failure. J Am Heart Assoc. 2017. https://doi. org/10.1161/jaha.117.005539.

71. Hensel KO. Non-ischemic diabetic cardiomyopathy may initially exhibit a transient subclinical phase of hyperdynamic myocardial performance. Med Hypotheses. 2016;94:7-10. https://doi.org/10.1016/ j.mehy.2016.06.002.

72. Athithan L, Gulsin GS, McCann GP, Levelt E. Diabetic cardiomyopathy: pathophysiology, theories and evidence to date. World $J$ Diabetes. 2019;10(10):490-510. https://doi.org/10.4239/wjd. v10.i10.490. 
73. Yan B, Liu S, Li X, Zhong Y, Tong F, Yang S. Preconditioning with endoplasmic reticulum stress alleviated heart ischemia/reperfusion injury via modulating IRE1/ATF6/RACK1/PERK and PGC-1 $\alpha$ in diabetes mellitus. Biomed Pharmacother. 2019;118:109407. https://doi.org/10.1016/j.biopha. 2019.109407.

74. Liu X, Yang R, Bai W, Xu X, Bi F, Zhu M, et al. Exploring the role of orexin B-sirtuin 1-HIF-1 $\alpha$ in diabetes-mellitus induced vascular endothelial dysfunction and associated myocardial injury in rats. Life Sci. 2019. https://doi.org/10.1016/j.lfs.2019. 117041 (Epub ahead of print).

75. Chesnaye NC, Szummer K, Bárány P, Heimbürger O, Magin H, Almquist T, et al. Association between renal function and troponin $\mathrm{T}$ over time in stable chronic kidney disease patients. J Am Heart Assoc. 2019;8(21):e013091. https://doi.org/10. 1161/JAHA.119.013091.

76. Hippisley-Cox J, Coupland C. Diabetes treatments and risk of heart failure, cardiovascular disease, and all cause mortality: cohort study in primary care. BMJ. 2016;354:i3477.

77. Ha V, Viguiliouk E, Kendall CWC, Balachandran B, Jenkins DJA, Kavsak PA, et al. Effect of a low glycemic index diet versus a high-cereal fibre diet on markers of subclinical cardiac injury in healthy individuals with type 2 diabetes mellitus: an exploratory analysis of a randomized dietary trial. Clin Biochem. 2017;50(18):1104-9. https://doi.org/ 10.1016/j.clinbiochem.2017.09.021.

78. Sugiura T, Dohi Y, Takase H, Yamashita S, Mizoguchi $\mathrm{T}$, Fujii $\mathrm{S}$, et al. Close association between circulating high-sensitivity cardiac troponin I and metabolic syndrome in the general population. Hypertens Res. 2019;42(11):1768-75. https://doi. org/10.1038/s41440-019-0283-X.

79. Haller PM, Boeddinghaus J, Neumann JT, Sörensen NA, Hartikainen TS, Goßling A, et al. Performance of the ESC 0/1-h and 0/3-h algorithm for the rapid identification of myocardial infarction without STelevation in patients with diabetes. Diabetes Care. 2019. https://doi.org/10.2337/dc19-1327 (Epub ahead of print).

80. Koren O, Azaizah M, Rozner E, Elias M, Turgeman Y. Role of thrombin generation assays in the diagnosis of acute myocarditis and non-ST myocardial infarction. J Thromb Thrombol. 2019. https://doi. org/10.1007/s11239-019-01996-6 (Epub ahead of print).

81. Ross SJ, Shah NH, Noutong Njapo SA, Cordiner DJ, Winchester DE. Use of cardiac troponin testing in the outpatient setting. South Med J. 2019;112(5):
295-300. 0000000000000971.

https://doi.org/10.14423/SMJ.

82. Leutner $M$, Tscharre $M$, Farhan $S$, Taghizadeh Waghefi H, Harreiter J, Vogel B, et al. A sex-specific analysis of the predictive value of troponin I and $\mathrm{T}$ in patients with and without diabetes mellitus after successful coronary intervention. Front Endocrinol (Lausanne). 2019;10:105. https://doi.org/10.3389/ fendo.2019.00105.

83. Bashir A, Azharuddin M, Rashid I, Murti K, Pandey K. Predictors of cardiomyopathy in patients with type- 2 diabetes mellitus with and without cardiovascular complications: a cross-sectional study. Diabetes Res Clin Pract. 2019;154:90-100. https:// doi.org/10.1016/j.diabres.2019.06.012.

84. Takahashi Y, Satoh M, Ohmomo H, Tanaka F, Osaki T, Tanno K, et al. Association between high-sensitivity cardiac troponin $\mathrm{T}$ and future cardiovascular incidence in a general Japanese population: results from the Tohoku medical megabank project. Biomarkers. 2019;24(6):566-73. https://doi.org/10. 1080/1354750X.2019.1606278.

85. Zelniker TA, Morrow DA, Mosenzon O, Gurmu Y, Im K, Cahn A, et al. Cardiac and inflammatory biomarkers are associated with worsening renal outcomes in patients with type 2 diabetes mellitus: observations from SAVOR-TIMI 53. Clin Chem. 2019;65(6):781-90. clinchem.2018.298489.

86. Green JB, Bethel MA, Armstrong PW, Buse JB, Engel SS, Garg J, TECOS Study Group, et al. Effect of sitagliptin on cardiovascular outcomes in type 2 diabetes. N Engl J Med. 2015;373:232-42.

87. White WB, Cannon CP, Heller SR, Nissen SE, Bergenstal RM, Bakris GL, EXAMINE Investigators, et al. Alogliptin after acute coronary syndrome in patients with type 2 diabetes. $\mathrm{N}$ Engl J Med. 2013;369(14):1327-35. https://doi.org/10.1056/ nejmoa1305889.

88. Nakata T, Hashimoto A, Hase M, Tsuchihashi K, Shimamoto K. Human heart-type fatty acid-binding protein as an early diagnostic and prognostic marker in acute coronary syndrome. Cardiology. 2003;99(2):96-104.

89. Pyati AK, Devaranavadagi BB, Sajjannar SL, Nikam SV, Shannawaz MS. Heart-type fatty acid binding protein: a better cardiac biomarker than CK-MB and myoglobin in the early diagnosis of acute myocardial infarction. J Clin Diagn Res. 2015;9(10): BC08-11. https://doi.org/10.7860/jcdr/2015/15132. 6684 .

90. Alhadi HA, Fox KA. Do we need additional markers of myocyte necrosis: the potential value of heart 
fatty-acid-binding protein. QJM. 2004;97(4): 187-98.

91. Ye XD, He Y, Wang S, Wong GT, Irwin MG, Xia Z. Heart-type fatty acid binding protein (H-FABP) as a biomarker for acute myocardial injury and longterm post-ischemic prognosis. Acta Pharmacol Sin. 2018;39(7):1155-63. https://doi.org/10.1038/aps. 2018.37.

92. Akbal E, Özbek M, Güneş F, Akyürek Ö, Üreten K, Delibaşı T. Serum heart type fatty acid binding protein levels in metabolic syndrome. Endocrine. 2009;36(3):433-7.

93. Başar O, Akbal E, Köklü S, Tuna Y, Koçak E, Başar N, et al. Increased H-FABP concentrations in nonalcoholic fatty liver disease. Possible marker for subclinical myocardial damage and subclinical atherosclerosis. Herz. 2013;38(4):417-22.

94. Narumi T, Shishido T, Kiribayashi N, Kadowaki S, Nishiyama S, Takahashi $\mathrm{H}$, et al. Impact of insulin resistance on silent and ongoing myocardial damage in normal subjects: the Takahata study. Exp Diabetes Res. 2012. https://doi.org/10.1155/2012/ 815098.

95. Viswanathan K, Kilcullen N, Morrell C, Thistlethwaite SJ, Sivananthan MU, Hassan TB, et al. Hearttype fatty acid-binding protein predicts long-term mortality and re-infarction in consecutive patients with suspected acute coronary syndrome who are troponin-negative. J Am Coll Cardiol. 2010;55(23): 2590-8. https://doi.org/10.1016/j.jacc.2009.12.062.

96. Schoenenberger AW, Stallone F, Walz B, Bergner M, Twerenbold R, Reichlin $\mathrm{T}$, et al. Incremental value of heart-type fatty acid-binding protein in suspected acute myocardial infarction early after symptom onset. Eur Heart J Acute Cardiovasc Care. 2015;5(2):185-92.

97. Rubin J, Matsushita K, Ballantyne CM, Hoogeveen $\mathrm{R}$, Coresh J, Selvin E. Chronic hyperglycemia and subclinical myocardial injury. J Am Coll Cardiol. 2012;59(5):484-9.

98. Cakir E, Ozbek M, Sahin M, Cakal E, Gungunes A, Ginis Z, et al. Heart type fatty acid binding protein response and subsequent development of atherosclerosis in insulin resistant polycystic ovary syndrome patients. J Ovarian Res. 2012;5(1):45.

99. Sari M, Kilic H, Ariturk OK, Yazihan N, Akdemir R. Diabetic patients have increased perioperative cardiac risk in heart-type fatty acid-binding proteinbased assessment. Med Princ Pract. 2015;24(1):53-7. https://doi.org/10.1159/000368756.

100. Chen K, Chen QJ, Wang LJ, Liu ZH, Zhang Q, Yang $\mathrm{K}$, et al. Increment of HFABP level in coronary artery in-stent restenosis segments in diabetic and nondiabetic minipigs: HFABP overexpression promotes multiple pathway-related inflammation, growth and migration in human vascular smooth muscle cells. J Vasc Res. 2016;53(1-2):27-38.

101. Beysel S, Kizilgul M, Ozbek M, Caliskan M, Kan S, Apaydin $M$, et al. Heart-type fatty acid binding protein levels in elderly diabetics without known cardiovascular disease. Clin Interv Aging. 2017;12: 2063-8. https://doi.org/10.2147/CIA.S137247.

102. Franczyk B, Gluba-Brzozka A, Rysz J. Biomarkers of cardiovascular risk in haemodialysis patients. Curr Pharm Des. 2018;23(39):6086-95. https://doi.org/ $10.2174 / 1381612823666170816114816$.

103. Yılmaz FH, Arı Yuca S, Vatansev H, Cimbek EA, Şen Y, Yılmaz İ, Akyürek F, et al. Heart-type fatty acid binding protein level as a tool in identification of early cardiac effects of diabetic ketoacidosis. J Clin Res Pediatr Endocrinol. 2017;9(2):118-23. https:// doi.org/10.4274/jcrpe.3961.

104. Altara R, Ghali R, Mallat Z, Cataliotti A, Booz GW, Zouein FA. Conflicting vascular and metabolic impact of the IL-33/sST2 axis. Cardiovasc Res. 2018;114(12):1578-94. https://doi.org/10.1093/cvr/ cvy166.

105. Pusceddu I, Dieplinger B, Mueller T. ST2 and the ST2/IL-33 signalling pathway-biochemistry and pathophysiology in animal models and humans. Clin Chim Acta. 2019;495:493-500. https://doi.org/ 10.1016/j.cca.2019.05.023.

106. Pascual-Figal DA, Januzzi JL. The biology of ST2: the International ST2 Consensus Panel. Am J Cardiol. 2015;115(7 Suppl):3B-7B. https://doi.org/10.1016/j. amjcard.2015.01.034.

107. Caporali A, Meloni M, Miller AM, Vierlinger K, Cardinali A, Spinetti G, et al. Soluble ST2 is regulated by p75 neurotrophin receptor and predicts mortality in diabetic patients with critical limb ischemia. Arterioscler Thromb Vasc Biol. 2012;32(12):e149-60. https://doi.org/10.1161/ ATVBAHA.112.300497.

108. Fousteris E, Melidonis A, Panoutsopoulos G, Tzirogiannis K, Foussas S, Theodosis-Georgilas A, et al. Toll/interleukin-1 receptor member ST2 exhibits higher soluble levels in type 2 diabetes, especially when accompanied with left ventricular diastolic dysfunction. Cardiovasc Diabetol. 2011;10:101. https://doi.org/10.1186/1475-284010-101.

109. Okar S, Kaypakli O, Şahin DY, Koç M. Fibrosis marker soluble ST2 predicts atrial fibrillation recurrence after cryoballoon catheter ablation of nonvalvular paroxysmal atrial fibrillation. Korean Circ 
J. 2018;48(10):920-9. https://doi.org/10.4070/kcj. 2018.0047.

110. Januzzi JL, Mebazaa A, Di Somma S. ST2 and prognosis in acutely decompensated heart failure: the International ST2 Consensus Panel. Am J Cardiol. 2015;115(7 Suppl):26B-31B. https://doi.org/10. 1016/j.amjcard.2015.01.037.

111. Cardellini M, Rizza S, Casagrande V, Cardolini I, Ballanti M, Davato F, et al. Soluble ST2 is a biomarker for cardiovascular mortality related to abnormal glucose metabolism in high-risk subjects. Acta Diabetol. 2019;56(3):273-80. https://doi.org/ 10.1007/s00592-018-1230-z.

112. Somuncu MU, Akgun T, Cakır MO, Akgul F, Serbest NG, Karakurt $\mathrm{H}$, et al. The elevated soluble ST2 predicts no-reflow phenomenon in ST-elevation myocardial infarction undergoing primary percutaneous coronary intervention. $\mathrm{J}$ Atheroscler Thromb. 2019;26(11):970-8. https://doi.org/10. $5551 /$ jat. 48413 .

113. Miller AM, Purves D, McConnachie A, Asquith DL, Batty GD, Burns H, Cavanagh J, Ford I, McLean JS, Packard CJ, Shiels PG, Turner H, Velupillai YN, Deans KA, Welsh P, McInnes IB, Sattar N. Soluble ST2 associates with diabetes but not established cardiovascular risk factors: a new inflammatory pathway of relevance to diabetes? PLoS ONE. 2012;7(10):e47830. https://doi.org/10.1371/ journal.pone.0047830.

114. Coglianese EE, Larson MG, Vasan RS, Ho JE, Ghorbani A, McCabe EL, et al. Distribution and clinical correlates of the interleukin receptor family member soluble ST2 in the Framingham Heart Study. Clin Chem. 2012;58(12):1673-81. https://doi.org/ 10.1373/clinchem.2012.192153 Epub 2012 Oct 11.

115. Jha D, Goenka L, Ramamoorthy T, Sharma M, Dhandapani VE, George M. Prognostic role of soluble ST2 in acute coronary syndrome with diabetes. Eur J Clin Invest. 2018;48(9):e12994. https://doi. org/10.1111/eci.12994.

116. Shimpo M, Morrow DA, Weinberg EO, Sabatine MS, Murphy SA, Antman EM, et al. Serum levels of the interleukin-1 receptor family member ST2 predict mortality and clinical outcome in acute myocardial infarction. Circulation. 2004;109(18):2186-90.

117. Sabatine MS, Morrow DA, Higgins LJ, MacGillivray C, Guo W, Bode C, et al. Complementary roles for biomarkers of biomechanical strain ST2 and N-terminal prohormone B-type natriuretic peptide in patients with ST-elevation myocardial infarction. Circulation. 2008;117:1936-44.

118. Berezin AE. Diabetes mellitus related biomarker: the predictive role of growth-differentiation factor- 15 .
Diabetes Metab Syndr. 2016;10(1 Suppl 1):S154-7. https://doi.org/10.1016/j.dsx.2015.09.016.

119. Ding Q, Mracek T, Gonzalez-Muniesa P, Kos K, Wilding J, Trayhurn P, Bing C. Identification of macrophage inhibitory cytokine- 1 in adipose tissue and its secretion as an adipokine by human adipocytes. Endocrinology. 2009;150:1688-96.

120. Bootcov MR, Bauskin AR, Valenzuela SM, Moore AG, Bansal M, He XY, et al. MIC-1, a novel macrophage inhibitory cytokine, is a divergent member of the TGF- $\beta$ superfamily. Proc Natl Acad Sci USA. 1997;94:11514-9.

121. Adela R, Banerjee SK. GDF-15 as a target and biomarker for diabetes and cardiovascular diseases: a translational prospective. J Diabetes Res. 2015. https://doi.org/10.1155/2015/490842.

122. Simm A, Nass N, Bartling B, Hofmann B, Silber RE, Navarrete Santos A. Potential biomarkers of ageing. Biol Chem. 2008;389:257-65.

123. Bermúdez B, López S, Pacheco YM, Villar J, Muriana FJ, Hoheisel JD, et al. Influence of postprandial triglyceride-rich lipoproteins on lipid-mediated gene expression in smooth muscle cells of the human coronary artery. Cardiovasc Res. 2008;79: 294-303.

124. Shin MY, Kim JM, Kang YE, Kim MK, Joung KH, Lee $\mathrm{JH}$, et al. Association between growth differentiation factor 15 (GDF15) and cardiovascular risk in patients with newly diagnosed type 2 diabetes mellitus. J Korean Med Sci. 2016;31(9):1413-8. https://doi.org/10.3346/jkms.2016.31.9.1413.

125. Kempf T, Guba-Quint A, Torgerson J, Magnone MC, Haefliger C, Bobadilla M, et al. Growth differentiation factor 15 predicts future insulin resistance and impaired glucose control in obese nondiabetic individuals: results from the XENDOS trial. Eur J Endocrinol. 2012;167(5):671-8. https://doi.org/10. 1530/EJE-12-0466.

126. Vila G, Riedl M, Anderwald C, Resl M, Handisurya A, Clodi M, Prager G, Ludvik B, Krebs M, Luger A. The relationship between insulin resistance and the cardiovascular biomarker growth differentiation factor-15 in obese patients. Clin Chem. 2011;57: 309-16.

127. Bao X, Borné Y, Muhammad IF, Nilsson J, Lind L, Melander $\mathrm{O}$, et al. Growth differentiation factor 15 is positively associated with incidence of diabetes mellitus: the Malmö Diet and Cancer-Cardiovascular Cohort. Diabetologia. 2019;62(1):78-86. https:// doi.org/10.1007/s00125-018-4751-7.

128. Hong JH, Chung HK, Park HY, Joung KH, Lee JH, Jung JG, et al. GDF15 is a novel biomarker for 
impaired fasting glucose. Diabetes Metab J. 2014;38: 472-9.

129. Schernthaner-Reiter MH, Itariu BK, Krebs M, Promintzer-Schifferl M, Stulnig TM, Tura A, et al. GDF15 reflects beta cell function in obese patients independently of the grade of impairment of glucose metabolism. Nutr Metab Cardiovasc Dis. 2019;29(4):334-42. https://doi.org/10.1016/j. numecd.2018.12.008.

130. Murakami T, Ueba Y, Shinoto Y, Koga Y, Kaneda D, Hatoko T, et al. Successful glycemic control decreases the elevated serum FGF21 level without affecting normal serum GDF15 levels in a patient with mitochondrial diabetes. Tohoku J Exp Med. 2016;239(2):89-94. https://doi.org/10.1620/tjem. 239.89 .

131. Khan SQ, Ng K, Dhillon O, Kelly D, Quinn P, Squire $\mathrm{IB}$, et al. Growth differentiation factor-15 as a prognostic marker in patients with acute myocardial infarction. Eur Heart J. 2009;30(9):1057-65. https://doi.org/10.1093/eurheartj/ehn600.

132. Bonaca MP, Morrow DA, Braunwald E, Cannon CP, Jiang $S$, Breher $S$, et al. Growth differentiation factor-15 and risk of recurrent events in patients stabilized after acute coronary syndrome: observations from PROVE IT-TIMI 22. Arterioscler Thromb Vasc Biol. 2011;31:203-10.

133. Kempf T, von Haehling S, Peter T, Allhoff T, Cicoira M, Doehner W, et al. Prognostic utility of growth differentiation factor-15 in patients with chronic heart failure. J Am Coll Cardiol. 2007;50(11): 1054-60.

134. Wallentin L, Hijazi Z, Andersson U, Alexander JH, De Caterina R, Hanna M, et al. Growth differentiation factor 15 , a marker of oxidative stress and inflammation, for risk assessment in patients with atrial fibrillation: insights from the apixaban for reduction in stroke and other thromboembolic events in atrial fibrillation (ARISTOTLE) trial. Circulation. 2014;130:1847-58.

135. Hamon SM, Griffin TP, Islam MN, Wall D, Griffin MD, O'Shea PM. Defining reference intervals for a serum growth differentiation factor-15 (GDF-15) assay in a Caucasian population and its potential utility in diabetic kidney disease (DKD). Clin Chem Lab Med. 2019;57(4):510-20. https://doi.org/10. 1515/cclm-2018-0534.

136. Nakajima T, Shibasaki I, Sawaguchi T, Haruyama A, Kaneda H, Nakajima T, et al. Growth differentiation factor-15 (GDF-15) is a biomarker of muscle wasting and renal dysfunction in preoperative cardiovascular surgery patients. J Clin Med. 2019. https://doi. org/10.3390/jcm8101576.
137. Anand IS, Kempf T, Rector TS, Tapken H, Allhoff T, Jantzen F, et al. Serial measurement of growth-differentiation factor-15 in heart failure: relation to disease severity and prognosis in the valsartan heart failure trial. Circulation. 2010;122:1387-95.

138. Hsu LA, Wu S, Juang JJ, Chiang FT, Teng MS, Lin JF, et al. Growth differentiation factor 15 may predict mortality of peripheral and coronary artery diseases and correlate with their risk factors. Mediators Inflamm. 2017;2017:9398401. https://doi.org/10. $1155 / 2017 / 9398401$

139. Dominguez-Rodriguez A, Abreu-Gonzalez P, Avanzas P. Usefulness of growth differentiation factor- 15 levels to predict diabetic cardiomyopathy in asymptomatic patients with type 2 diabetes mellitus. Am J Cardiol. 2014;114:890-4.

140. Natali A, Nesti L, Venturi E, Shore AC, Khan F, Gooding K, SUMMIT consortium, et al. Metformin is the key factor in elevated plasma growth differentiation factor-15 levels in type 2 diabetes: A nested, casecontrol study. Diabetes Obes Metab. 2019;21(2): 412-6. https://doi.org/10.1111/dom.13519.

141. Lu J, Zhang Y, Dong X, Lu J, Zhang C, Liu J, et al. Association between MIC-1 and type 2 diabetes: a combined analysis. Dis Mark. 2019;2019:7284691. https://doi.org/10.1155/2019/7284691.

142. Tang M, Luo M, Lu W, Wang S, Zhang R, Liang W, et al. Serum growth differentiation factor 15 is associated with glucose metabolism in the third trimester in Chinese pregnant women. Diabetes Res Clin Pract. 2019;156:107823. https://doi.org/10. 1016/j.diabres.2019.107823.

143. Li F, Ruan X, Min L. Targeting both sides of the GDF15-GFRAL-RET receptor complex: A new approach to achieve body weight homeostasis. Genes Dis. 2017;4(4):183-4. https://doi.org/10. 1016/j.gendis.2017.11.004.

144. Tsai VWW, Husaini Y, Sainsbury A, Brown DA, Breit $\mathrm{SN}$. The MIC-1/GDF15-GFRAL pathway in energy homeostasis: implications for obesity, cachexia, and other associated diseases. Cell Metab. 2018;28(3): 353-68. https://doi.org/10.1016/j.cmet.2018.07.018.

145. Suthahar N, Meijers WC, Silljé HHW, Ho JE, Liu FT, de Boer RA. Galectin-3 activation and inhibition in heart failure and cardiovascular disease: an update. Theranostics. 2018;8(3):593-609. https://doi.org/ $10.7150 /$ thno. 22196 .

146. Tan KCB, Cheung CL, Lee ACH, Lam JKY, Wong Y, Shiu SWM. Galectin-3 is independently associated with progression of nephropathy in type 2 diabetes mellitus. Diabetologia. 2018;61(5):1212-9. https:// doi.org/10.1007/s00125-018-4552-z. 
147. Luís C, Costa R, Rodrigues I, Castela Â, Coelho P, Guerreiro S, et al. Xanthohumol and 8-prenylnaringenin reduce type 2 diabetes-associated oxidative stress by downregulating galectin-3. Porto Biomed J. 2018;4(1):e23. https://doi.org/10.1016/j. pbj.0000000000000023.

148. Berezin A. Metabolic memory phenomenon in diabetes mellitus: achieving and perspectives. Diabetes Metab Syndr. 2016;10(2 Suppl 1):S176-83. https:// doi.org/10.1016/j.dsx.2016.03.016.

149. Hernández-Romero D, Vílchez JA, Lahoz Á, Romero-Aniorte AI, Jover E, García-Alberola A, et al. Galectin-3 as a marker of interstitial atrial remodelling involved in atrial fibrillation. Sci Rep. 2017;7: 40378. https://doi.org/10.1038/srep40378.

150. Holmager P, Egstrup M, Gustafsson I, Schou M, Dahl JS, Rasmussen LM, et al. Galectin-3 and fibulin-1 in systolic heart failure - relation to glucose metabolism and left ventricular contractile reserve. BMC Cardiovasc Disord. 2017;17(1):22. https://doi. org/10.1186/s12872-016-0437-6.

151. Keng BMH, Gao F, Ewe SH, Tan RS, Teo LLY, Xie BQ, et al. Galectin-3 as a candidate upstream biomarker for quantifying risks of myocardial ageing. ESC Heart Fail. 2019;6(5):1068-76. https://doi.org/10. 1002/ehf2.12495.

152. Atalar MN, Abuşoğlu S, Ünlü A, Tok O, İpekçi SH, Baldane $S$, et al. Assessment of serum galectin-3, methylated arginine and hs-CRP levels in type 2 diabetes and prediabetes. Life Sci. 2019;231:116577. https://doi.org/10.1016/j.lfs.2019.116577.

153. Vora A, de Lemos JA, Ayers C, Grodin JL, Lingvay I. Association of galectin-3 with diabetes mellitus in the dallas heart study. J Clin Endocrinol Metab. 2019;104(10):4449-58. https://doi.org/10.1210/jc. 2019-00398.

154. Gopal DM, Ayalon N, Wang YC, Siwik D, Sverdlov A, Donohue C, et al. Galectin-3 is associated with stage B metabolic heart disease and pulmonary hypertension in young obese patients. J Am Heart Assoc. 2019;8(7):e011100. https://doi.org/10.1161/ JAHA.118.011100.

155. Flores-Ramírez R, Azpiri-López JR, González-González JG, Ordaz-Farías A, González-Carrillo LE, CarrizalesSepúlveda EF, et al. Global longitudinal strain as a biomarker in diabetic cardiomyopathy. A comparative study with Gal-3 in patients with preserved ejection fraction. Arch Cardiol Mex. 2017;87(4): 278-85. https://doi.org/10.1016/j.acmx.2016.06.002.

156. Sun Z, Wang Z, Li L, Yan J, Shao C, Bao Z, et al. RAGE/galectin-3 yields intraplaque calcification transformation via sortilin. Acta Diabetol. 2019;56(4): 457-72. https://doi.org/10.1007/s00592-018-1273-1.
157. Tan KCB, Cheung CL, Lee ACH, Lam JKY, Wong Y, Shiu SWM. Galectin-3 and risk of cardiovascular events and all-cause mortality in type 2 diabetes. Diabetes Metab Res Rev. 2019;35(2):e3093. https:// doi.org/10.1002/dmrr.3093.

158. Berezin AE, Kremzer AA, Martovitskaya YV, Berezina TA, Gromenko EA. Pattern of endothelial progenitor cells and apoptotic endothelial cell-derived microparticles in chronic heart failure patients with preserved and reduced left ventricular ejection fraction. EBioMedicine. 2016;4:86-94. https://doi. org/10.1016/j.ebiom.2016.01.018.

159. Scheen AJ. Cardiovascular Effects of New Oral Glucose-Lowering Agents: DPP-4 and SGLT-2 Inhibitors. Circ Res. 2018;122(10):1439-59. https://doi. org/10.1161/CIRCRESAHA.117.311588.

160. Home P. Cardiovascular outcome trials of glucoselowering medications: an update. Diabetologia. 2019;62(3):357-69. https://doi.org/10.1007/ s00125-018-4801-1.

161. Januzzi JL Jr, Butler J, Jarolim P, Sattar N, Vijapurkar $U$, Desai $M$, et al. Effects of canagliflozin on cardiovascular biomarkers in older adults with type 2 diabetes. J Am Coll Cardiol. 2017;70(6):704-12. https://doi.org/10.1016/j.jacc.2017.06.016.

162. Pennica D, Shaw KJ, Swanson TA, Moore MW, Shelton DL, Zioncheck KA, et al. Cardiotrophin-1. Biological activities and binding to the leukemia inhibitory factor receptor/gp130 signaling complex. J Biol Chem. 1995;270:10915-22. https://doi.org/ 10.1074/jbc.270.18.10915.

163. Stephens J, Ravussin E, White U. The expression of adipose tissue-derived cardiotrophin-1 in humans with obesity. Biology (Basel). 2019. https://doi.org/ 10.3390/biology8020024.

164. Escoté X, Gómez-Zorita S, López-Yoldi M, MiltonLaskibar I, Fernández-Quintela A, Martínez JA, et al. Role of omentin, vaspin, cardiotrophin-1, TWEAK and NOV/CCN3 in obesity and diabetes development. Int J Mol Sci. 2017. https://doi.org/10.3390/ ijms18081770.

165. Natal C, Fortuño MA, Restituto P, Bazán A, Colina I, Díez J, et al. Cardiotrophin-1 is expressed in adipose tissue and upregulated in the metabolic syndrome. Am J Physiol Endocrinol Metab. 2008;294:E52-60. https://doi.org/10.1152/ajpendo.00506.2007.

166. Moreno-Aliaga MJ, Pérez-Echarri N, Marcos-Gómez B, Larequi E, Gil-Bea FJ, Viollet B, et al. Cardiotrophin-1 is a key regulator of glucose and lipid metabolism. Cell Metab. 2011;14(2):242-53. https://doi.org/10.1016/j.cmet.2011.05.013. 
167. López-Yoldi M, Stanhope KL, Garaulet M, Chen XG, Marcos-Gómez B, Carrasco-Benso MP, et al. Role of cardiotrophin-1 in the regulation of metabolic circadian rhythms and adipose core clock genes in mice and characterization of 24-h circulating CT-1 profiles in normal-weight and overweight/obese subjects. FASEB J. 2017;31(4):1639-49. https://doi. org/10.1096/fj.201600396RR.

168. López-Yoldi M, Moreno-Aliaga MJ, Bustos M. Cardiotrophin-1: a multifaceted cytokine. Cytokine Growth Factor Rev. 2015;26:523-32. https://doi. org/10.1016/j.cytogfr.2015.07.009.

169. Rendo-Urteaga T, García-Calzón S, Martínez-Ansó E, Chueca M, Oyarzabal M, Azcona-Sanjulián MC, et al. Decreased cardiotrophin-1 levels are associated with a lower risk of developing the metabolic syndrome in overweight/obese children after a weight loss program. Metabolism. 2013;62:1429-36. https://doi.org/ 10.1016/j.metabol.2013.05.011.

170. Hung HC, Lu FH, Wu HT, Ou HY, Yang YC, Wu JS, et al. Cardiotrophin-1 is inversely associated with obesity in non-diabetic individuals. Sci Rep. 2015;5: 17438. https://doi.org/10.1038/srep17438.

171. Malavazos AE, Ermetici F, Morricone L, Delnevo A, Coman C, Ambrosi B, et al. Association of increased plasma cardiotrophin-1 with left ventricular mass indexes in normotensive morbid obesity. Hypertension. 2008;51:e8. https://doi.org/10.1161/ HYPERTENSIONAHA.107.105346.

172. de Simone G. Morbid obesity and left ventricular geometry. Hypertension. 2007;49(1):7.

173. Briana DD, Germanou K, Boutsikou M, Boutsikou T, Athanasopoulos N, Marmarinos A, et al. Potential prognostic biomarkers of cardiovascular disease in fetal macrosomia: the impact of gestational diabetes. J Matern Fetal Neonatal Med. 2018;31(7): 895-900. https://doi.org/10.1080/14767058.2017. 1300651.

174. Gamella-Pozuelo L, Fuentes-Calvo I, Gómez-Marcos MA, Recio-Rodriguez JI, Agudo-Conde C, Fernández-Martín JL, et al. Plasma cardiotrophin-1 as a marker of hypertension and diabetes-induced target organ damage and cardiovascular risk. Medicine (Baltimore). 2015;94(30):e1218. https://doi.org/10. 1097/MD.0000000000001218.

175. Kitahara T, Takeishi $Y$, Arimoto $T$, Niizeki $T$, Koyama Y, Sasaki T, et al. Serum carboxy-terminal telopeptide of type I collagen (ICTP) predicts cardiac events in chronic heart failure patients with preserved left ventricular systolic function. Circ J. 2007;71(6):929-35.

176. Duprez DA, Gross MD, Kizer JR, Ix JH, Hundley WG, Jacobs DR Jr. Predictive Value of Collagen biomarkers for heart failure with and without preserved ejection fraction: MESA (Multi-Ethnic Study of Atherosclerosis). J Am Heart Assoc. 2018. https:// doi.org/10.1161/jaha.117.007885.

177. Ferreira JM, Ferreira SM, Ferreira MJ, Falcão-Pires I. Circulating biomarkers of collagen metabolism and prognosis of heart failure with reduced or mid-range ejection fraction. Curr Pharm Des. 2017;23(22): 3217-23. 1381612823666170317124125 .

178. Sundström J, Vasan RS. Circulating biomarkers of extracellular matrix remodeling and risk of atherosclerotic events. Curr Opin Lipidol. 2006;17(1):45-53.

179. Lieb W, Song RJ, Xanthakis V, Vasan RS. Association of circulating tissue inhibitor of metalloproteinases1 and procollagen type III aminoterminal peptide levels with incident heart failure and chronic kidney disease. J Am Heart Assoc. 2019;8(7):e011426. https://doi.org/10.1161/JAHA.118.011426.

180. Eschalier R, Fertin M, Fay R, Bauters C, Zannad F, Pinet $F$, et al. Extracellular matrix turnover biomarkers predict long-term left ventricular remodeling after myocardial infarction: insights from the REVE-2 study. Circ Heart Fail. 2013;6(6): 1199-205. https://doi.org/10.1161/ CIRCHEARTFAILURE.113.000403.

181. Parikh VN, Liu J, Shang C, Woods C, Chang AC, Zhao M, et al. Apelin and APJ orchestrate complex tissue-specific control of cardiomyocyte hypertrophy and contractility in the hypertrophy-heart failure transition. Am J Physiol Heart Circ Physiol. 2018;315(2):H348-56. https://doi.org/10.1152/ ajpheart.00693.2017.

182. Dalzell JR, Rocchiccioli JP, Weir RA, Jackson CE, Padmanabhan N, Gardner RS, et al. The emerging potential of the apelin-APJ system in heart failure. J Card Fail. 2015;21(6):489-98. https://doi.org/10. 1016/j.cardfail.2015.03.007.

183. Ni T, Lin N, Huang X, Lu W, Sun Z, Zhang J, et al. Icariin ameliorates diabetic cardiomyopathy through Apelin/Sirt3 signalling to improve mitochondrial dysfunction. Front Pharmacol. 2020;11: 256. https://doi.org/10.3389/fphar.2020.00256.

184. Schulte C, Karakas M, Zeller T. microRNAs in cardiovascular disease-clinical application. Clin Chem Lab Med. 2017;55(5):687-704. https://doi. org/10.1515/cclm-2016-0576.

185. Soler-Botija C, Gálvez-Montón C, Bayés-Genís A. Epigenetic biomarkers in cardiovascular diseases. Front Genet. 2019;10:950. https://doi.org/10.3389/ fgene.2019.00950. 